\title{
A Note On Mobility Determinants In Canada, 1965-1971
}

\author{
Anthony L. Ostrosky* \\ I. INTRODUCTION
}

Recently, Grant and Vanderkamp (1976) have analyzed the determinants (and to a lesser degree, the effects) of geographic mobility in Canada. Using Unemployment Insurance Commission (UIC) data, Grant and Vanderkamp disaggregate migration flows according to a variety of demographic traits, including sex, age, occupation, and income. Among the exogenous factors postulated as influencing migration are income, distance, and population.

Overall, Grant and Vanderkamp do a thorough and technically sound analysis of interregional migration; however, they may have omitted a number of important considerations in their analysis. For example, they fail in any direct way to disaggregate migration flows according to the employment (unemployment) status of migrants. Clearly, there is every reason to expect differences in the propensity to migrate as between employed and unemployed persons. Moreover, there is every reason to expect differences in the variables influencing the migration decisions of the employed on the one hand and the unemployed on the other. Thus, failure to disaggregate according to employment (unemployment) status may result in specification bias. Similarly, once one disaggregates by employment (unemployment) status, one must consider the new (different) variables which are likely to influence each migrant group. Along these lines, it seems reasonable to hypothesize that welfare benefit levels may be an important determinant of the migration of the unemployed, especially in view of the enormous geographic welfare benefit differentials existing in Canada. The unemployed individual may view welfare benefits as a form of long-term unemployment compensation and/or as a form of income per se; hence, welfare may very well be an argument in his decision calculus.

Accordingly, the purpose of this Note is to examine the possible impact of geographic welfare differentials on interregional migration in Canada. The focus is on a net migration to Canada's 22 largest central metropolitan areas (CMA's) over the 1965-1971 period. ${ }^{1}$ The model is structurally somewhat similar to Grant and Vanderkamp in its inclusion of the income and population variables. 


\section{AN INITIAL MODEL}

To examine the migration impact of welfare in Canada, we initially postulate the following model:

(1) $\mathrm{N}_{\mathrm{i}}=\mathrm{a}_{0}+\mathrm{a}_{1} \mathrm{Y}_{\mathrm{i}}+\mathrm{a}_{2} \mathrm{~W}_{\mathrm{i}}+\mathrm{a}_{3} \mathrm{P}_{\mathrm{i}}+\mu$

where $\mathrm{N}_{\mathrm{i}}=$ net number of unemployed migrants to $\mathrm{CMA}_{\mathrm{i}}, 1965-1971$, expressed as a percentage of $\mathrm{CMA}_{\mathrm{i}}$ 's 1965 population $^{2}$

$\mathrm{a}_{0}=$ constant

$\mathrm{Y}_{\mathrm{i}}=1965$ per capita income in $\mathrm{CMA}_{\mathbf{i}}$

$\mathrm{W}_{\mathrm{i}}=1965$ per recipient welfare benefit level in $\mathrm{CMA}_{\mathbf{i}}$

$\mathrm{P}_{\mathrm{i}}=1965$ total population in $\mathrm{CMA}_{\mathrm{i}}$

$\mu=$ error term ${ }^{3}$

In accord with conventional migration theory, we would expect that $\mathrm{a}_{1}>$ 0 . That is, migrants are hypothesized as being attracted by the prospect of a higher income, ceteris paribus. Next, since welfare may be viewed by these migrants as a form of income per se and/or as a form of long term unemployment benefits, they presumably should be attracted by the prospect of higher welfare levels, ceteris paribus; hence, we argue that $\mathrm{a}_{2}>0$. Finally, following Grant and Vanderkamp (1976, p. 34), we argue that population size is a surrogate for employment opportunities. That is, the larger the CMA's population, the greater the expected job opportunities, ceteris paribus: $\mathrm{a}_{3}>0$.

Estimating equation (1) by OLS yields

(2) $\mathrm{N}_{\mathrm{i}}=-.109-.053 \mathrm{Y}_{\mathrm{i}}+1.107 \mathrm{~W}_{\mathrm{i}}+.001 \mathrm{P}_{\mathrm{i}}$

$$
\begin{aligned}
& (-.75)(-.68) \\
& \mathrm{R}^{2}=.95, \mathrm{DF}=18, \mathrm{~F}=113.4
\end{aligned}
$$

where terms in parentheses are t-values.

In result (2), two of the three coefficients $\left(a_{2}, a_{3}\right)$ have the correct signs; moreover, these same coefficients are statistically significant at far beyond the .01 level. The coefficient of determination is .95 , so that the model explains roughly 95 percent of the variation in the dependent variable (the unemployed migration rate). Finally, the F-ratio is significant as well, at far beyond the .01 level.

Clearly, the results in equation (2) indicate that unemployed migrants are strongly and positively influenced by the prospect of higher welfare benefits and by population size in the destination CMA, where (as noted above) the latter is a proxy for employment opportunities.

\section{AN ALTERNATIVE MODEL}

As an alternative to the model in equation (1), we have also estimated the following regression:

(3) $\mathrm{N}_{\mathrm{i}}=\mathrm{b}_{0}+\mathrm{b}_{1} \mathrm{Y}_{\mathrm{i}}+\mathrm{b}_{2} \mathrm{~W}_{\mathrm{i}}+\mathrm{b}_{3} \mathrm{U}_{\mathrm{i}}+\mu^{*}$ 


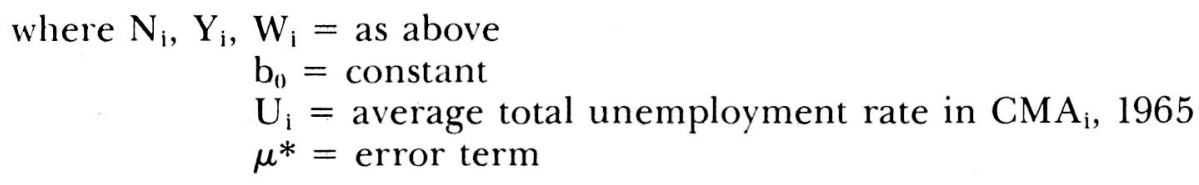

Following our discussion in Section II above, the following signs on coefficients in (3) are to be expected:

(4) $b_{1}, b_{2}>0$

In addition, following conventional migration theory, we would expect that $b_{3}<0$. This is on the grounds that the higher the unemployment rate in an area, the greater the risk of not being able to secure gainful employment, ceteris paribus. This model differs from that in regression (1) in the substitution of variable $U_{i}$ for variable $P_{i}$.

The OLS estimate of regression equation (3) is

(5) $\mathrm{N}_{\mathrm{i}}=-.439 \quad-.066 \mathrm{Y}_{\mathrm{i}}+1.008 \mathrm{~W}_{\mathrm{i}}-.002 \mathrm{U}_{\mathrm{i}}$

$$
\begin{array}{llll}
(-1.89) \quad(-.57) \quad(+9.21) \quad(-1.88) & 0
\end{array}
$$

$$
\mathrm{R}^{2}=.85, \mathrm{DF}=18, \mathrm{~F}=33.6
$$

where terms in parentheses are, once again, t-values.

These results are fairly similar to those in (2). Two of the three coefficients $\left(b_{2}, b_{3}\right)$ have the expected sign; in addition, one $\left(b_{3}\right)$ is significant at about the .06 level, whereas a nother $\left(b_{2}\right)$ is significant at well beyond the .01 level. Thus, as in regression (2), welfare plays a critical role in the migration of unemployed persons.

\section{CONCLUSION}

This Note has attempted to extend the recent Grant and Vanderkamp (1976) study of Canadian mobility. The empirical findings strongly suggest that it is relevant to disaggregate migration according to employment (unemployment) status and to examine the role of welfare as a determinant of the migration of the unemployed.

Given the apparent influence of Canadian welfare differentials over geographic mobility, it would seem very worthwhile to investigate whether human resource misallocation is occurring. It may be that greater welfare benefit uniformity in Canada would act as a weaker distorting factor in migration flows; that is a matter beyond the scope of this Note, however.

\section{FOOTNOTES}

'The CMA's studied in this paper were Calgary, Alb., Chicoutimi, Que., Edmonton, Alb., Halafax, N.S., Hamilton, Ont., Kitchener, Ont., London, Ont., Montreal, Que., Ottawa, Que., Quebec, Que., Regina, Sask., St. Catharines, Ont., St. John's, Nfld., St. John, N.B., Saskatoon, Sask., Sudbury, Ont., Thunder Bay,
Ont., Toronto, Ont., Vancouver, B.C., Victoria, B.C., Windsor, Ont., and Winnipeg, Man.

${ }^{2}$ This is a standard representation of the migration rate as a dependent variable. Related to this, see Cebula and Vedder (1973), Pack (1973), or Sommers and Suits (1973). 
${ }^{3}$ The data were scaled [see, e.g., Grant and Vanderkamp (1976)] to allow for "readable" coefficients. The welfare datit were provided by Allan Sleeman; other data sources were Census of Canada: 1971, Vol. 3, Part 1, Economic Characteristics, Table 6, pp. 1-10, (Bulletin 3.1 3). January 1975: Census of Canada: 1971, Vol. 1, Part 5,
Population, Table 23, pp. 1-70, (Bulletin 1.5 - 8), May 1975: Census of Canada: 1971, Vol. 1, Part 3, Population, Table 22, pp. 1-8, (Bulletin 1.3 - 4), A pril 1973; and Census of Canada: 1971, Vol. 3, Part 1, Economic Characteristics, Table 41, pp. 1-2, (Bulletin 3.1 - 14), April 1975.

\section{REFERENCES}

Cebula. R. J. and Vedder, R. K., "A Note on Migration, Fconomic Opportunity, and the Quality of Life," Journal of Regional Science, Vol. 13, August, 1973, pp. 205-211.

Grant, F.. and Vanderkamp, J., The Economic Causes and Effects of Migration: Canada, 1965-71, Ottawa, Canada: fconomic Council of Canada, 1976.
Pack, J. R., "Determinants of Migration to Central Cities," Journal of Regional Science, Vol. 13, August, 1973, pp. 249-260.

Sommers, P. M. and Suits, D. B., "Analysis of Net Interstate Migration," Southern Economic Journal, Vol. 40, October, 1973, pp. 193-201. 